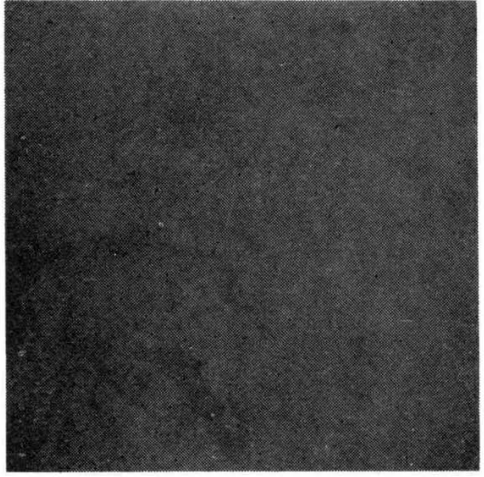

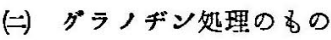

すなわち全くどれる処理しないものは（1)のようと素 地がはっきりと認められるが，サンドブラストをほどこ したものは (口) のようとポリエチレンがー部表面付付着 したまま残っている。けはサンドベーパーでこすった

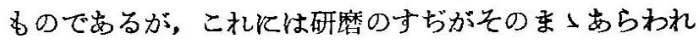
ている。:は年ラノヂン処理をはどこしたるのであっ て、これはは独がポリエチレンが残っている。

以上の絬果からサンドブラストが前処理としてすぐれ ていることが判ったが，化学处理をはどこしたものはこ

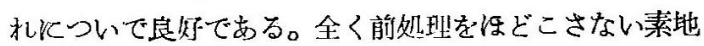

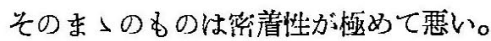

\title{
電着クロムの擴散に関する研究*
}

$$
\text { 上. 田重 } \text { 朋 }^{* *}
$$

\section{The Diffusion of Electro-deposited Chromium into Pure Iron}

\section{Shigetomo UEDA}

Many chromium plated articles are often used at high temperature. In these cases various phenomena occur providing advantages or disadvantages for use. The diffusion which occurs between an electro-deposited metal and a base metal is one of the important phenomena. In the present work, pure iron directly chromium plated has been heated in a vacuum, and then the diffusion coefficient and the activation energy have been calculated.

\section{I . 緒 言}

クロム・メッキ梳政用，队蝕用また耐摩耗用として 広く用いられている。工業の進歩とともにこれらのあの が离温で使用される場合が多くなった。クロム・メッキ が嗑温にさらされるとき，種々の現象が生じるが，なか でも被覆金属であるクロムと素地金属との临化生じる掘 散現象は重要なるのと思われる。

本研究においては，純鉄にクロムを直接メッキした試 片を真空中で種々の温度に加熱保持し，鉄けへのクロム の拡散現象を基儊的に検钨し搪散係数 $D$ ならびに $\log D$ と絶対温度の逆数 1/T との関係から, 活性化エネルギ 一Qを求めた。

拡散現象を利用して，雷着ク口ムと素地との合金化を 行い，ク口ム㐿の密着性を改善するという考党がある。 また，電着クロムを素地の鉄鋼と完全に合金化して，表 面首を鉄一ク口ム系合金とし，クロムの溜度勾配をもた せることも考觉られている。これらはクロマイジグの

* 炤和 30 年11月，本協会12回講演会（大陑） 火て発唕

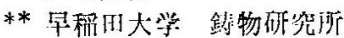

一方法とみなし得る。しかし，これらの可倠は别執で報 告することとし，本報では述べな。

\section{II. 実 験 方 法}

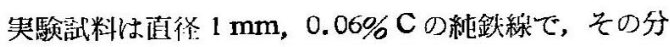
析值は, $0.06 \% \mathrm{C}, 0.05 \% \mathrm{Si}, 0.36 \% \mathrm{Mn}, 0.018 \% \mathrm{P}$,

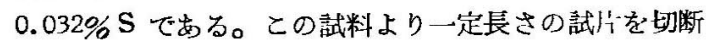

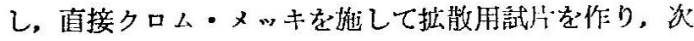
にこれらを第 1 图に示す真空加熱装圆によって抈熱・椧 却を行い，霞着クロムを素地の純鉄中门搪散させた。抬

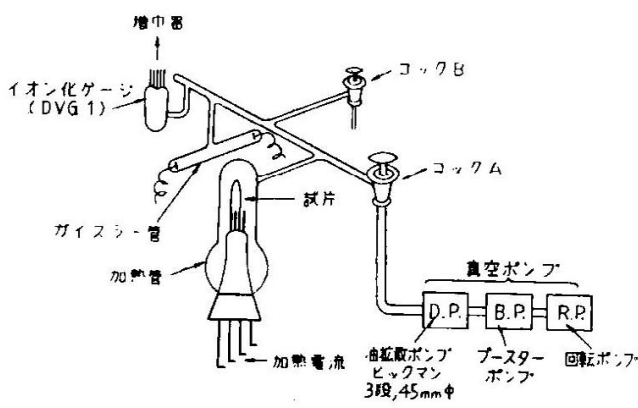

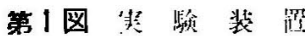


散量の決定は，加熱前括よび冷却後に扔ける陚片の横断

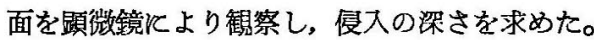

(1) クロム・メッキ

試料の純鉄線より第 2 図のごとく，約 $12 \mathrm{~cm}$ の試片を 切断し，一端を極に保持し，約 $11 \mathrm{~cm} の$ 部分に直接ク口 ム・メッキを揓した。

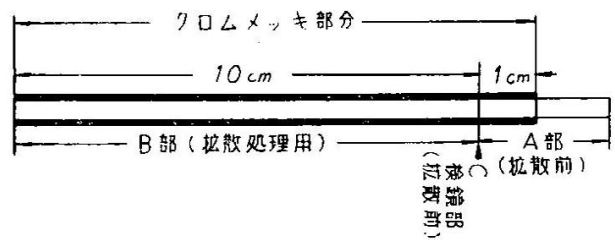

第2図䛊们少法

メッキ方法は JIS H9121 飞作業標集が示されてい るので, 本実験に扔いてもこれに準じてィッキを行った が，「作業標準」は防蝕・装飾用を主目的としたわので あるから，そのまますへてて適用するわけとゆかない。 すなかち，本実験では央駼の目的から，鉄素地飞直接ク ロムを電着させるメッキ方法を採用したい。それ故，一 般䏓クム・メッキの標準浴と考えられて扣り，かつ鉄

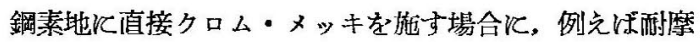
耗用クロム・メッキの場合等飞, 広く用いられている無 水ク口ム酸 $250 \mathrm{~g} / l$, 硫酸 $2.5 \mathrm{~g} / l$ の浴を採用した。

クロム・メッキはメッキ条件によって電青状態が著し く異なるるのであり，数多くの研究がなされているは， 3),-5,5。これらの諸研究の結果飞基ついて，本実験 の メッキ条件を決定しなけ狄ホならないが，実験の目的か ら，クロム・メッキした試片をある温度である時間加熱 保持しク口ムの拡散を行わせた後と抬いてる，陚片の最 外凰にはな拉末だ拡散が行われていないクロム圈が残存 していることが必要である。換言すれば，クロムをある 厚さメッキした試片を用意しなけれげならない。

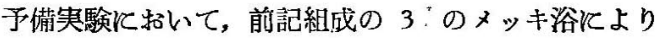
浴温度・電流密度・電着時間を種々变化して武片にメッ キを湤し，重量增加，寸沠変化（同一試片について10筒 所）を測定しまたメッキ風の厚さを梌鏡して，浴温度 を $50^{\circ} \mathrm{C}$, 電流密度を $60 \mathrm{amp} / \mathrm{dm}^{2}$, 電鄯時間を $30 \sim 180$

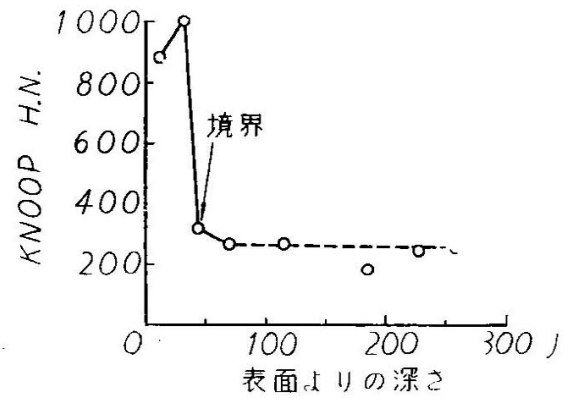

第3図微小硬度計によるメッキ層の硬度 min とメッキ条件を決定した。苐3図は，決定したメッ キ条件でメッキされた試片の微小硬度測定結果の 1 例で ある。硬翼クロム・メッキが施されているととが判る。

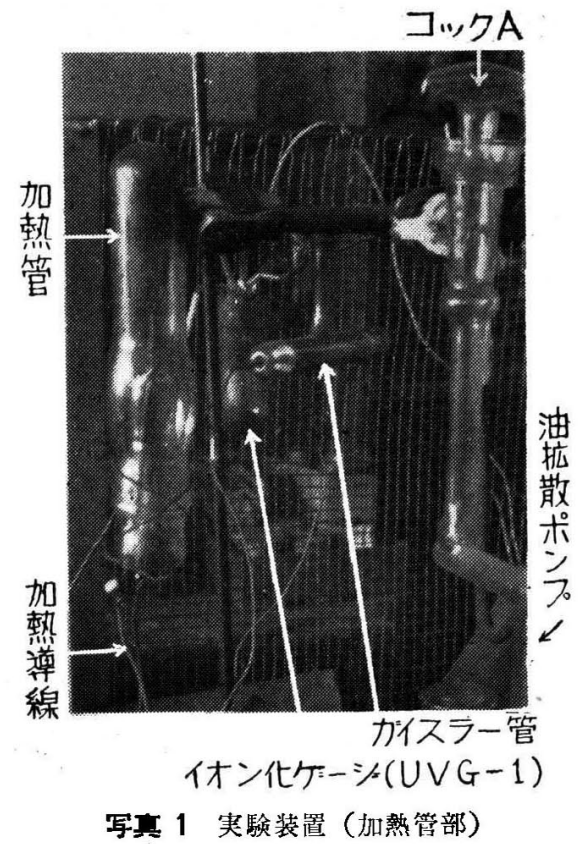

（2）真空加熱法

実験装置の概略を第 1 図括よび写而 1 亿示す。拉散用 試片は第 1 図和よび第 4 図のよう亿加熱管内の極に接続 する。試片の加熱は，直接試片飞電流を通じて行う。

実験の順序は次の通りである。試片を極に接続した後

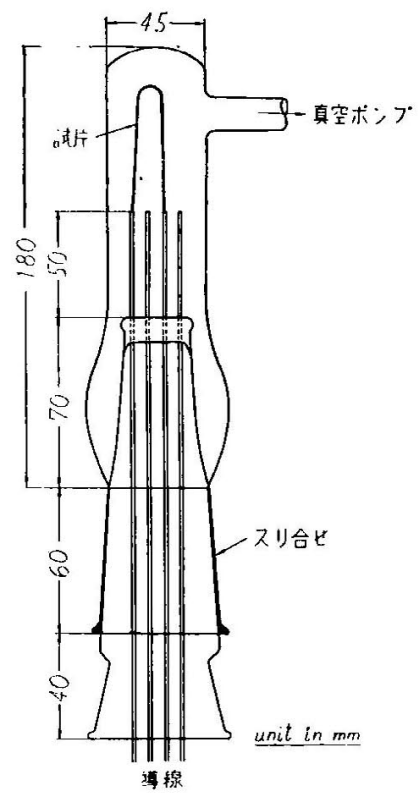

牶4図玑熱 管 
第1図コックAを開いて加熱管内を真空に引く，管内の 圧力が所要の生力に達した後, 陚片に電流を通し，抬散 の温度より低い温度（後述する温度測定法によって 400 $\sim 500^{\circ} \mathrm{C}$ ) 飞 $30 \sim 40 \mathrm{~min}$ 間一定飞保持して予借加熱を

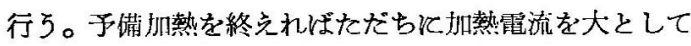
抎散温度に上げ，一定時間保持し抬散处理を行万。搪散 処理を終えれば電流を切断し，そのまま冷却を行い試片 が窒温に達した後, 第1図コックAを閉じ真空ポンプ系 と加熱管を中絶し，管内の試片を取り出す。

今们の実験籁井々, $900 \sim 1200^{\circ} \mathrm{C}, 30 \mathrm{~min} \sim 6 \mathrm{hr}$. の 加熱保持である。また，真空度は. $10^{-5} \mathrm{mmHg}$ の籍井 で行い，真空度の測定とはイオン化ゲーシ（UVGI）を 用いた。な拉，温度の決定沠が間題となるが，これにつ いては次と述へる。

(3) 㧈熱電流と或片温度

本垁験では，陚片に直接電流を通じ真空中で加熱する のである。陚片は直径 $1 \mathrm{~mm}$ の線材武料より長さ $10 \mathrm{~cm}$ そ切断したるのであるから，各武片の直径括よび長さは 一定であり，一定抵抗值を有するわけである。㐾って， 試片飞流す電流を精密飞謂整できれば，武片の加熱・冷 却を正確に制御できる。実験では精密級の電流計を使用 Lた。

各武片を加熱するごとと測溫するのが理想的である が, 実験装置の関係上繁雑となりかつ困蜼でもある。し かるに，試片の加熱電流は精密汇調整できるのであるか ら，加熱電流飞対する試片の温度を予め測定して括け ば，その後は同一形状寸泆のるのを武片として加熱する 限り，加熱電流を知ればその時の武片温度が判るわけで ある。すなわち，搪散実験に用いるのと同し寸法の試片 そついて加熱電流と温度との関係を求め，「加熱電流と 試片温度」曲線を作成して和けげよい。

温度の測定には光高温棓十用いた。熱雪対を用いるの が普通であるが，試片の直佳が極めて小であるとと，ま た加熱された試片によるふく射熱の影響，さら熱電対 を吅熱管外に引き出すという技術的な間題等の理由から 本実験で熱電対を用いなかった。光高温計の使用に当 って，その対物レンズを延げし焦点距離を短かくして州 熱管にできるだけ接近し (約 $50 \mathrm{~cm}$ ), 光高温計の視野 内K見觉るフィラメントの形状 (ヘ形) と加熱試片の像 (八形) とが丁度一致するように光高温訣を固定静置し た。測温の場合には，さらに加熱管の周囲を黑色厚手の 紙で包み，外部自然光の影響を極力避け，湘定誤差が入 るのを防いた。。

光高温計を用いる場合，光高温計の指示温度に対する 補正々，被測定融片の表面ふく射 (Emissivity) 飞対す る補正を必要とする。前者の補正は，計器自体の間題で あるので使用計器の製作所飞依頼し，本実験の測濫が加
熱管外より行 5 関係上，ガラス賢を通して測温した場合 の補正值を求めて鿓った。後者の補正は，研究者侄よっ てその「ふく射係教 $E$ 」と多少の相違があるが日)，本央 験の実験簀囲を考虑して，E=0.40 とした。

拡散用試片と同じ形状寸法の試片A，B，C 3 個を用 意し（クロム・メッキを施してない），㞦熱需流々試片 温度との関係を求めた結果は第 5 図である。第 5 図より 試片の㧈熱電流を制御するととにより試片を任意の温度 そ州熱することができる。

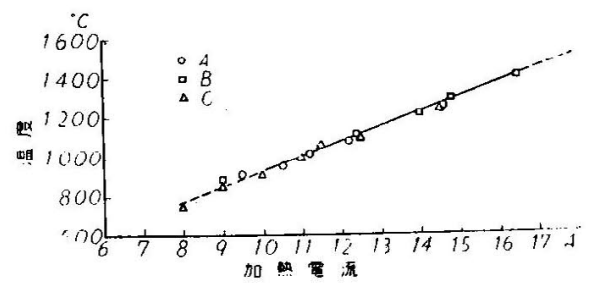

第 5 図加熱電流と試片温度との関係

(4) クロムの侵入の梁さの決定

クロムの侵入の深さの決定は次の通りである。第 2 図 そ示すように,メッキを推した試片より $10 \mathrm{~cm}$ 長さの㹡 散用武片を切断し，その残余の部分を昖散前の武片とし て断面要研磨し㭘鏡した（図のC部）。拉敞後は試片の中 央部で切断，切断面を检鏡した。検鏡のための腐蝕液は 硝酸アルコール溶液を用いた。写真 2 亿示すように, ク ロム・メッキ層招よび昖散㲏は腐蝕されず白色带状のま まである。搪散試片の場合，この白色帯状の部分と素地

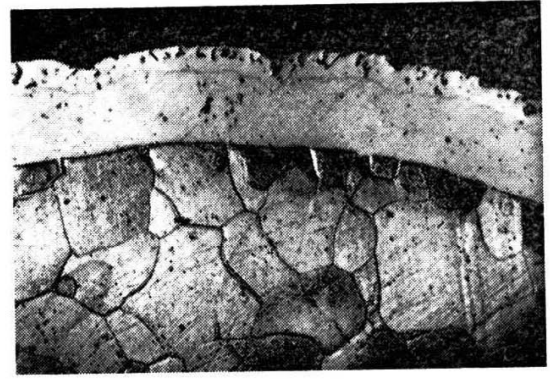

写真 2 搪散後の䞒片断面

(频微鏡 $\times 320$ 写真 $\times 1 / 2$ )

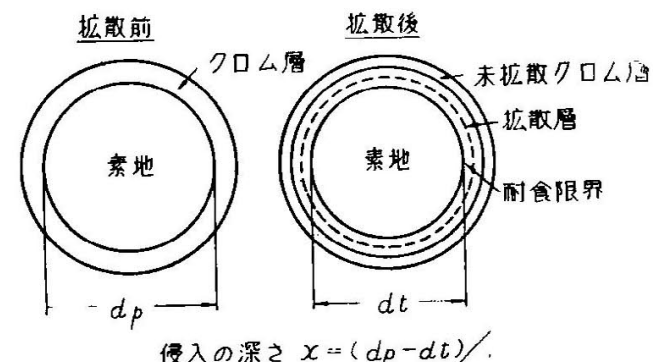

第6図 侵入の深さの苫義 
の純鉄組織との境界面は G. Tammann 7) の耐蝕限界 (Resistanzgrenze) であって, 約 $14 \% \mathrm{Cr}$ の濃度であ る。クロムの侵入の澡さは第 6 図に示すように, 拡散前 と抬散後の試片を検鏡し抎散前の素地部分の直径 $d p$ と 抎散後の上記耐蝕限界内の直径 $d t$ を求め, 両者の差の ז/2と定義した。 $d p, d t$ の測定には顕微鏡の接腿測微言十 を用いた。

\section{III. 実 験 結 果}

前節に述べた実験方法でクロム・メッキをした試片を $920,1000,1030,1100,1150$ 扎よび $1200^{\circ} \mathrm{C}$ の各温度 で0.5〜 6hr 加熱保持し，抎散を行わせた。実験結果を 述べれば次のごとくである。

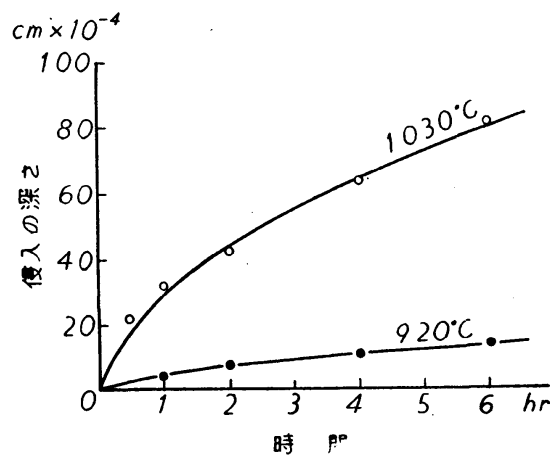

第7図，侵入の深さと時間

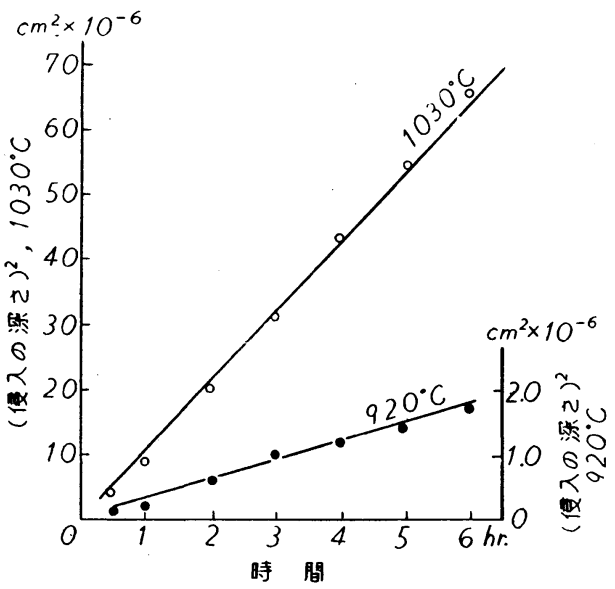

第 8 図（侵入の深さ $)^{2}$ と時間との関係

第 7 図は, 一定温度に括ける侵入の梁さと時間との関 係であって，抛物線的関係が成立する。第 7 図の結果よ り，(侵入の深さ) ${ }^{2}$ と時間との関係を求めると第 8 図の ごとくになる。すなわち，(侵入の深さ $)^{2}$ と時間との間 飞直線的関係が成立している。次に, 処理時間を $3 \mathrm{hr}$ 一定として侵入の深さに及ぼす温度の影響を求めると,

第 9 図が得られ，温度の上昇ととるに侵入の深さは急激

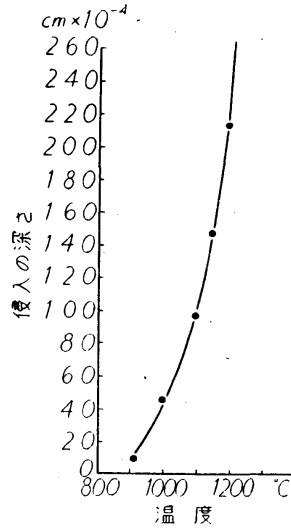

第9図 侵入の深さと温度 との関係

に増州することが判る。

今，まる温度で $t$ 時間の拡散を行ったとき，最初の境 界面の位置飞扮ける濃度をC 搪散係数を $D$ とすれば。 Fick の法則から次式が成立 する。

$$
1-\frac{C_{x}}{C_{0}}=\frac{2}{\sqrt{\pi}} \int_{0}^{\frac{x}{2 \sqrt{D t}}} e^{-\omega^{2}} d \omega^{2}
$$

ここマ $\omega=x / 2 \sqrt{D t}$ であって, Gauss の誤差函数を導 大すれば，式 (1) は簡単にすることができる。すなわち $x^{2}=4 A D t$

で, 上式の $A$ は $C_{x} / C_{0}$ に関する定数で, Gauss の䅡 分表より求められるものである。

侵入の深さを第6図のごとく定義したので，夷験で得 た值は上式の $x$ 亿相当する。 $C_{x}$ は耐蝕限界であるから， $C_{x}=14 \% \mathrm{Cr}, C_{0}$ は最初の濃度の $/ 2, C_{0}=100 / 2=50 \% \mathrm{Cr}$, しかるときは $A=0.584$ が得られ，式 (2) は

$$
x^{2}=2.34 D t
$$

となる。

第9四より上式によって $D$ を算出し，絶対温度の逆 数 $1 / T$ と $\log D$ との関係を求めると第10図のごとくで ある。 $1 / T$ と $\log D$ との間值線関係が成立している ので, $D=K \cdot e-Q / R T$ より活性化エネルギー $Q$ を求める

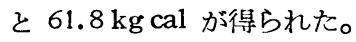

\section{IV. 総 括}

クロムを電着した純鉄は真空中で加熱し，クロムを鉄 中に拡散させて, 拡散の温度および時間が侵入の深さに 扣よぼす影響を求めた。これらの実験値より，第1表沉 示す拡散係数 $D$ 等決定し, 活性化エネルギー $Q$ を算 出して $61.8 \mathrm{kgcal} を$ を得た。 
第1表 鉄中のクロム拡散係数

\begin{tabular}{c|c|c}
\hline${ }^{\circ} \mathrm{C}$ & $1 / \mathrm{T}$ & $D \mathrm{~cm}^{2} / \mathrm{sec}$ \\
\hline 920 & $8.38 \times 10^{-1}$ & $1.3 \times 10^{-10}$ \\
950 & 8.17 & $2.4 \times 10^{-10}$ \\
1000 & 7.85 & $6.6 \times 10^{-10}$ \\
1030 & 7.67 & $1.1 \times 10^{-9}$ \\
1050 & 7.56 & $1.6 \times 10^{-9}$ \\
1100 & 7.28 & $4.0 \times 10^{-9}$ \\
1150 & 7.03 & $8.6 \times 10^{-9}$ \\
1200 & 6.78 & $1.9 \times 10^{-8}$ \\
\hline
\end{tabular}

終り飞, ·本研究に御指導を睗った飯高一郎教授飞厚く

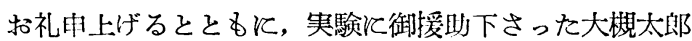
氏.また実験に協力した幸田吉生・福島宏幸の両群に感 謝の意を表する。

\section{文献}

（1）武井 武: 金属学大系, 9巻, 231 .

(2) 岸 松平 : 応用物理, 12, (1943)， 479 .

(3) 安藤修三 : 金属, 1949-2, 15 .

(4) 村上 透：錙金化学, 231 .

(5) R. Bilhinger : Das Hartverchromungverfahren, 1939, 23; Hernn. Beyer Verlag., Leipzig.

(6) 日本学術振與会学術第19小委員会報告, 高温飞関す 万研究, 64, 65 .

(7) G. Tammann : Z. anorg. Chem. 107, (1919), 1.

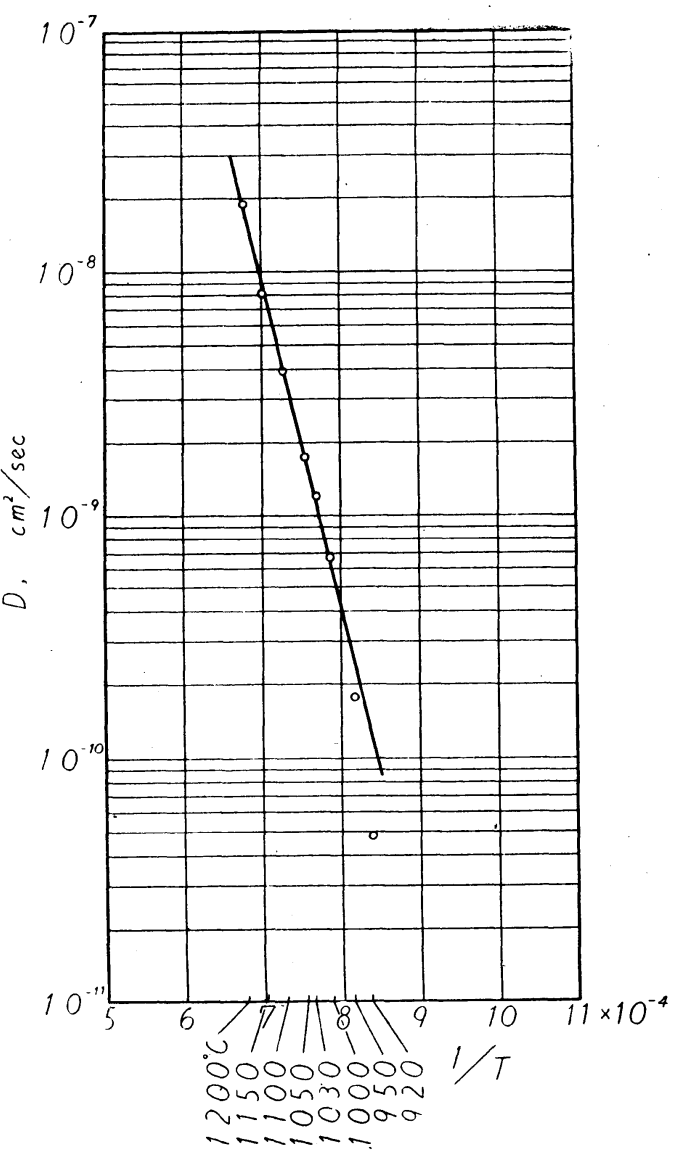

第10因 $\log \mathrm{D}$ と $1 / \mathrm{T}$ との関係

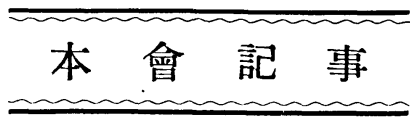

\section{一会镜- -}

○第56回理事会（31.4.17 於レストラン東京）3月分事 業報告, 運営委員会, 日本工学会大会記念展覧会, 燿 射特集号, 秀季講演大会, J S R 等に图し協墥した。 (この記事は会誌第 2 号に掦載すべきもの）

O学協会連絡委員会（31.5.21 於日本化学会会請室）当 協会より浅原評㼁員が出席，13回研究発表大会を，日 本化学会，電気化学協会，と共倠与る詳細次ついて打 合わせた。

OJSR連合編集委責会（31.5.25 於鉄鋼協会会䔐室） 英文抄録の書き方等飞関し具体的打合わせを行った。 ○日本工学会総会 (31.6.1 於工業具楽部) 当協会より 村上常務理事が出席し，特江大会記念展覧会の成果の 報告，今後の運営方針等の協議に参画した。

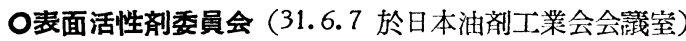
今迄の活動状況の総括的報告ののち今後の研究方針等 に関する打合わせを行った。
○表面活性㶡委員珗談会（31.6. 7 於レストラン・ダイ マス）油剤関係者とメッキ関係者との研究拈よび普及 に関する連絡のあり方等について賏談を行った。

○亜鉛ダイカスト・メッキ委員会（31.6.8 於レストラ ン木婏会館）西鉊ダイカストとそのメッキの普及に関 する゙講演会を企画した。

\section{○亜鉛ダイカストとそのメッキに関する鿁演会実行委是}

会 (31.6.9 於当協会会義室) 委員長吉田忠氏と事務 局とで上記講演会の会場の決定等の詳細を夷行に移し 始めた。

Oメッキ部会扯録委員会 (31.6.9 於レストラン木婏会 館）次回発行の抄録汇つき討議，「嗍弗轵塩溶液より の銅鍍金」扣よび「良いメッキのための良い水洗法」 を発行する事价た。つで文献抄録会員名簿の作 成, 会員の希望抄録の調查，正誤表揭載関する件， 表紙作成に関する件，および原稿料に関する件を討議 した。（42面につづく） 